\title{
Touristic Bicycle Accidents in Princess Islands: A Retrospective Cohort Study
}

\author{
[D Avni Uygar Seyhan, ${ }^{1}$ (1) Sevim Şen, ${ }^{2}$ 이 Nihat Müjdat Hökenek, \\ (1) Erdal Yılmaz,' 마 Rohat Ak
}

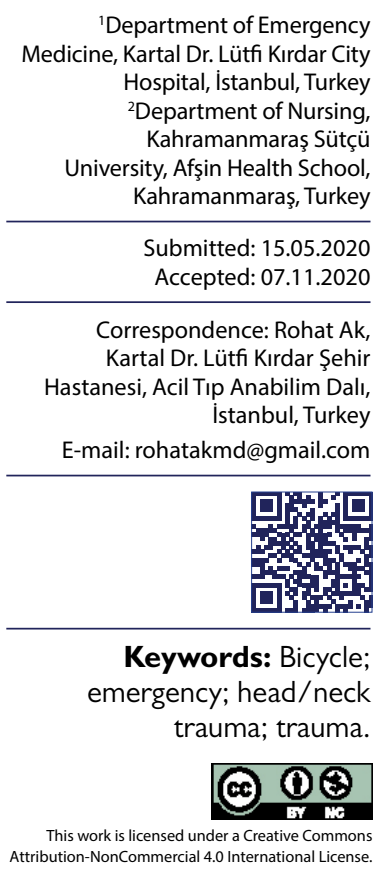

\begin{abstract}
Objective: This study aims to identify the characteristics of applicants arriving at the emergency department due to bicycle-related injuries.
\end{abstract}

Methods: This study was designed as an epidemiological, retrospective and descriptive analysis study. The cases between 2014 and 2019 presented in this study with bicycle-related injuries to the Department of Emergency of S.B.U. Istanbul Kartal Dr. Lutfi Kırdar Training and Research Hospital from Princess Island were analyzed retrospectively. The relevant data were recorded by examining patient files available in the electronic data of the hospital. Patient records from the last five years were examined and the data regarding bicycle accidents were evaluated concerning sociodemographic attributes, accident properties, trauma characteristics and mortality characteristics.

Results: In this study, 1582 patients were included. $58.1 \%$ of the patients $(n=919)$ were male, and the average age was $24.14 \pm 11.95$. None of the patients had personal protective measures (e.g., helmets and knee pads). The major areas exposed to trauma were the lower/ upper extremity with $63.2 \%(n=993)$ and the head/neck with $21 \%(n=333)$. The mortality rate was $0.8 \%(n=12)$.

Conclusion: In the bicycle accidents, the individuals classified under the young age group were affected. Head/neck trauma and intraparenchymal bleeding were the main cause of mortality. It was observed that the victims were not taking security measures such as helmets.

\section{INTRODUCTION}

Traffic accidents continue to be an important problem in our country. Fatalities and injuries may occur depending on the accident type, whereas such accidents stand as a burden for the national economy. In our country, bicycles are used for transportation and sports/recreation purposes. The increase in the use of bicycles and the lack of safety measures, such as helmets, raise the rate of injuries caused by accidents. ${ }^{[1-5]}$

According to the statistics concerning the traffic accidents that resulted in fatalities/injuries kept by the General Directorate of Security, 8514 of $3007 / 4$ accidents in 2018 were bicycle accidents. This rate is approximately $3 \%$ of all accidents. ${ }^{[6]}$ It is thought that epidemiological studies on the characteristics of bicycle accidents will contribute to literature and the process of accident prevention. In this study, the characteristics of patients arriving at the emergency department with injuries caused by bicycle use were examined.

\section{MATERIALS AND METHODS}

This work was designed as an epidemiological, retrospective and descriptive study. The cases between 2014 and 2019 presented in this study with bicycle-related injuries to the emergency department Kartal Dr. Lütfi Kırdar City Hospital were analyzed retrospectively. The bikers arriving at the hospital with bicycle-related injuries were included in this study. The criteria for inclusion and exclusion in/ from this study are described as follows.

\section{Inclusion criteria}

I- Applying from Buyukada Neighborhood in Princess Islands District of Istanbul or to be taken by II 2 District Ambulance Service by Princess Islands District of Istanbul

2- Arriving due to the bicycle accident.

Exclusion criteria

I- Patients with multiple trauma caused by vehicle accidents. 


\section{2- Patients residing in the Princess Islands}

Permission was obtained for this study from the Ethics Committee of Kartal Dr. Lütfi Kırdar City Hospital (Ethics Committee Document No: 2019/5/4//46/I2). The data collected through the hospital computer records were saved on the data collection form. The data collection form included certain parameters, such as age, gender, weather, injury zones, ISS (Injury Severity Score) score and mortality characteristics. The data in the data collection form was then transferred to SPSS (Statistical Package for Social Sciences, version 20 for Windows) software and analyzed accordingly. The assessment was made with frequency, mean, Mann-Whitney $U$ test, Fisher Exact Test and Yates Chi-Square Test (Continuity Correction). The results were analyzed within a $95 \%$ confidence interval and $\mathrm{p}<0.05$ was accepted as statistically significant.

\section{RESULTS}

For our study, 1994 patients were transferred from the Islands with II2 Emergency or by personal applications to our hospital located in the Islands. One hundred ten of these patients were excluded from this study since motor vehicles (tractors, ATV motorcycles) were involved in the accident and 15 patients due to residing in the Islands and 287 patients due to data unavailability. The remaining 1582 patients were included in this study. It was observed that the accidents were mostly $97.7 \%(n=919)$ in dry weather and $72.7 \%(n=\mid 150)$ during the daytime and $59.4 \%(n=939)$ during the weekdays. In addition, the sample group did not use protective equipment, such as helmets and knee pads.

In this study, $58.1 \%(n=919)$ of the sample group were male with an average age of 24.14 11 I.95. The ISS score range from 0 to 75 and the average was $2.47 \pm 4.99,1.8 \%$ $(n=28)$ had major ISS score (ISS score $>16)$. The mortality rate was $0.8 \%(n=12)$.

Given the distribution of trauma zones, $63.2 \%(n=993)$ lower/upper limb trauma and $21 \%(n=333)$ head and neck trauma occurred in the sample group. When the distribution of trauma zones was examined in more detail, the findings showed that traumas occurred by $22.5 \%(n=356)$ on wrists/hands, $15.3 \%(n=242)$ on elbows, $12.7 \%(n=201)$

Table I. Descriptive features $(n=\mid 582)$

\begin{tabular}{|c|c|c|c|}
\hline & n (\%) & & Mean $\pm S D$ \\
\hline Female & 663 (4I.9) & The average age $(I-80)$ & $24.14 \pm 11.95$ \\
\hline Male & $919(58.1)$ & Injury severity score $(0-75)$ & $2.47 \pm 4.99$ \\
\hline Dry weather & I $546(97.7)$ & & \\
\hline Rainy weather & $35(2.2)$ & & \\
\hline Daytime & $1150(72.7)$ & & \\
\hline Weekdays & $939(59.4)$ & & \\
\hline Injury severity score minor & I554 (98.2) & & \\
\hline Injury severity score major & $28(1.8)$ & & \\
\hline Mortality & $12(0.8)$ & & \\
\hline Use of protective equipment & $0(0)$ & & \\
\hline Distribution of the trauma regions & n (\%) & & n (\%) \\
\hline Frontal injury & $155(9.8)$ & Forearm & $112(7.1)$ \\
\hline Zygoma & $26(1.6)$ & Clavicle & $12(0.8)$ \\
\hline Mandible & $89(5.6)$ & Shoulder & $101(6.4)$ \\
\hline Maxilla & $30(1.9)$ & Arm & $160(10.1)$ \\
\hline Nasal & $27(1.7)$ & Elbow & $242(15.3)$ \\
\hline Subdural & $6(0.4)$ & Knee & $201(12.7)$ \\
\hline Epidural & $2(0.1)$ & Femur & $6(0.4)$ \\
\hline Intraparenchymal & $9(0.6)$ & Hip & $24(1.5)$ \\
\hline Scalp & $37(2.3)$ & Tibia / Fibula & $72(4.6)$ \\
\hline Skull & $2(0.1)$ & Foot / Ankle & $113(7.1)$ \\
\hline Cervical & $17(1.1)$ & Hand / Wrist & $356(22.5)$ \\
\hline Thorax & $9(0.6)$ & Thorax laceration & $23(1.5)$ \\
\hline Lumbar & $24(1.5)$ & Rib fracture & $5(0.3)$ \\
\hline Sacrum & $3(0.2)$ & & \\
\hline Outer abdomen abrasion & $28(1.8)$ & Head / neck trauma & $333(2 I)$ \\
\hline Spleen & I (0.I) & Lower / Upper limb trauma & $993(63.2)$ \\
\hline Bowel perforation & $I(0.1)$ & & \\
\hline Pelvis & $7(0.4)$ & & \\
\hline
\end{tabular}


on knees and $10.1 \%(n=160)$ on arms. The findings also showed that $9.8 \%(n=155)$ of the sample group had a frontal injury, and $5.6 \%(n=89)$ had a mandibular trauma. Descriptive features are indicated in Table $\mathrm{I}$.

Given the relationship with mortality, the obtained data were given as follows: The average age of the mortal group was $29.42 \pm 17.191$ and there was no relationship between mortality and average age. The average score of the mortal group was $29.25 \pm 14.410$, whereas all fatalities had major ISS scores. Accordingly, a highly significant relationship was found between ISS score and mortality $(p=0.000)$. It was observed that there was a highly significant relationship between lower/upper limb trauma and mortality, but this relationship was because non-mortal ones had lower/ upper limb trauma. As a result, $91.7 \%(n=11)$ of those with head/neck trauma were deceased and there was a highly significant relationship between head/neck trauma and mortality $(p=0.000)$. It was determined that $58.3 \%(n=7)$ of those with intraparenchymal hemorrhage deceased and a highly significant relationship $(p=0.000)$ was found between intraparenchymal bleeding and mortality. In the sample group those exposed to head/neck trauma without limb trauma and had intraparenchymal bleeding, the mortality rate was highly significant $(p=0.000)$. Only $25 \%(n=3)$ of mortal patients had subdural bleeding, and $16.7 \%(n=2)$ had epidural bleeding $(p=0.000)$. Mortality-related features are indicated in Table 2.

Mortality rate was $0.8 \%(n=12)$ on 1582 patients examined. The age ranged between 5 and 59 . ISS scores ranged from 25 to 75 . The characteristics of the cases resulting in mortality are shown in Table 3.

\section{DISCUSSION}

Bicycle use and the rate of bicycle accidents increase gradually in our country and the world. ${ }^{[7-10]}$ In the Van Baar et al. ${ }^{\left[{ }^{[1]}\right]} 2017$ study, it has been reported that I50,000 bicycle accidents are reported annually in the Netherlands. In the statistics of the General Directorate of Security in our country, the rate of bicycles involved in the accident was

Table 2. Mortality-related features $(n=\mid 582)$

\begin{tabular}{|c|c|c|c|c|}
\hline & Mortal $(n=12)$ & Non-Mortal $(n=1570)$ & Test statistics & $\mathbf{p}$ \\
\hline & Mean $\pm S D$ & Mean $\pm S D$ & & \\
\hline Age $29.42 \pm 17.191$ & $24.10 \pm 11.908$ & $Z=-1.094$ & 0.274 & \\
\hline \multirow[t]{3}{*}{ Injury severity score } & $29.25 \pm 14.410$ & $2.27 \pm 4.255$ & $Z=-6.170$ & $0.000^{*}(\mathrm{M})$ \\
\hline & Mortal $(n=12)$ & Non-Mortal $(n=1570)$ & $\mathbf{x}^{2}$ & $\mathbf{p}$ \\
\hline & n (\%) & n (\%) & & \\
\hline \multicolumn{5}{|l|}{ Injury severity score } \\
\hline Minor & $0(0)$ & 1554 (99) & 671.090 & $0.000^{* * * * *}(\mathrm{FE})$ \\
\hline Major & $12(100)$ & $16(1)$ & & \\
\hline \multicolumn{5}{|c|}{ Lower / Upper limb traumas } \\
\hline Yes & $0(0)$ & $993(63.2)$ & 20.386 & $0.000^{* * * *}$ (FE) \\
\hline No & $12(100)$ & $577(36.8)$ & & \\
\hline \multicolumn{5}{|l|}{ Subdural } \\
\hline Yes & $3(25)$ & $3(0.2)$ & 193.997 & $0.000^{* * * *}$ (FE) \\
\hline No & $9(75)$ & $1567(99.8)$ & & \\
\hline \multicolumn{5}{|l|}{ Epidural } \\
\hline Yes & $2(16.7)$ & $0(0)$ & 261.998 & $0.000^{* * * *}(\mathrm{FE})$ \\
\hline No & $10(83.3)$ & $1570(100)$ & & \\
\hline \multicolumn{5}{|l|}{ Intraparenchymal } \\
\hline Yes & $7(58.3)$ & $2(0.1)$ & 713.265 & $0.000^{* * * *}(\mathrm{FE})$ \\
\hline No & $5(41.7)$ & $1568(99.9)$ & & \\
\hline \multicolumn{5}{|l|}{ Cervical } \\
\hline Yes & $3(25)$ & $14(0.9)$ & 65.111 & $0.000^{* * *}(\mathrm{FE})$ \\
\hline No & $9(75)$ & I556 (99.1) & & \\
\hline \multicolumn{5}{|l|}{ Head / Neck Trauma } \\
\hline Yes & II (9I.7) & $322(20.5)$ & 36.284 & $0.000^{* * a * *}(\mathrm{FE})$ \\
\hline No & I (8.3) & $1248(79.5)$ & & \\
\hline \multicolumn{5}{|l|}{ Sex } \\
\hline Female & $8(66.7)$ & $655(41.7)$ & 2.106 & $0.147(\mathrm{YA})$ \\
\hline Male & $4(33.3)$ & $915(58.3)$ & & \\
\hline
\end{tabular}

FE: $X^{2}$ : Fisher Exact Test; M: Mann-Whitney U Test; YA: Yates Kikare Test (Continuity Correction). 
Table 3. Characteristics of the cases resulting in mortality

\begin{tabular}{|c|c|c|c|c|}
\hline & Age & Sex & $\begin{array}{l}\text { ISS } \\
\text { score }\end{array}$ & Diagnosis \\
\hline 1 & 29 & Male & 75 & Cervical trauma \\
\hline 2 & 5 & Male & 25 & Cervical trauma \\
\hline 3 & 12 & Female & 25 & $\begin{array}{l}\text { Epidural bleeding, } \\
\text { Cervical trauma }\end{array}$ \\
\hline 4 & 27 & Female & 25 & Intraparenchymal bleeding \\
\hline 5 & 59 & Female & 25 & Intraparenchymal bleeding \\
\hline 6 & 16 & Male & 25 & $\begin{array}{l}\text { Subdural bleeding, } \\
\text { Intraparenchymal bleeding }\end{array}$ \\
\hline 7 & 35 & Female & 25 & Intraparenchymal bleeding \\
\hline 8 & 47 & Female & 25 & Subdural bleeding \\
\hline 9 & 20 & Female & 26 & $\begin{array}{l}\text { Frontal trauma, } \\
\text { Intraparenchymal bleeding, } \\
\text { Cervical trauma }\end{array}$ \\
\hline 10 & 26 & Male & 25 & Subdural bleeding \\
\hline 11 & 20 & Female & 25 & $\begin{array}{l}\text { Epidural bleeding, } \\
\text { Intraparenchymal bleeding }\end{array}$ \\
\hline 12 & 57 & Female & 25 & Intraparenchymal bleeding \\
\hline
\end{tabular}

$0.4 \%$ in 2008 and $3 \%$ in 2018 . It can be expressed that the rate of bicycle use for transportation and recreational purposes is increasing gradually. ${ }^{[12]}$

In this study, it is underlined that all patients suffering from bicycle accidents consist of domestic and foreign tourists transferred by ambulance service in Adalar District of Istanbul Province. Bicycle-related fatalities and injuries may affect labor and tourism potential.

Although it is legally mandatory to use helmets while using bicycles in some countries, there is no such rule in our country. Article 150 of Road Traffic Regulation mentioned only the necessity to use helmets for motorbikes. However, there is no specific regulation for bicycle users. Güngör et al. ${ }^{[13]}$ and Güzel et al. ${ }^{[5]}$ stated that none of the patients arriving at the hospital due to a bicycle accident were actually wearing a helmet. Studies on helmet use indicate that helmet use reduces the rate of head injury risk by $63-88 \% .^{[1,14-17]}$ In this study, the cause of mortality was mostly head/neck trauma, suggesting the possibility of preventing these deaths using helmets.

In our study, the development rate of head/neck trauma was $21 \%(n=333)$. In the study of Koçak et al.," ${ }^{[1]}$ it was stated that injuries related to bicycles resulted mostly in head/neck traumas. In the study of Heng et al., ${ }^{[2]}$ the findings showed that the development rate of head trauma due to a bicycle accident was $36.3 \%$. In the study examining the relationship between those who used helmets and those who did not use in bicycle and e-bicycle accidents by Baschera et al., ${ }^{[18]}$ the findings showed that $68.4 \%(n=82)$ of the patients diagnosed with head trauma consisted of bicycle users without helmets. In further similar studies in the literature, the development rate of head trauma due to bicycle use varies between $8 \%$ and $43 \% .{ }^{[19-24]}$ In this respect, the rate obtained in our study complies with the literature.

In 1582 patients examined, the mortality rate was $0.8 \%$ $(n=12)$. As a result, $91.7 \%(n=I I)$ of those with head/ neck trauma deceased, and there was a highly significant relationship between head/neck trauma and mortality $(p=0.000)$. Due to head/neck trauma, intraparenchymal bleeding rate was $0.6 \%(n=9)$, subdural bleeding rate was $0.4 \%(n=6)$, epidural bleeding rate was $0.1 \%(n=2)$, frontal was $9.8 \%(155)$, zygoma $1.6 \%(n=26)$, mandible $5.6 \%$ $(n=89)$, maxilla I.9\% $(n=30)$, nasal I.7\% $(n=27)$, scalp $2.3 \%$ $(n=37)$, skull bone $0.1 \%(n=2)$ and cervical trauma rate was $1.1 \%(n=17) .58 .3 \%(n=7)$ of the patients with intraparenchymal bleeding deceased and a highly significant relationship $(p=0.000)$ was found between intraparenchymal bleeding and mortality. In the study performed by Heng et al., ${ }^{[2]}$ the mortality rate was $1.9 \%(3 / 160)$ and the cause of mortality was related to head trauma. In the study performed by Özkan et al.,"25] the injuries arising from bicycle accidents were analyzed and the cause of mortality was head trauma. In the study of Baschera et al., ${ }^{[8]}$ the relationship between the ones wearing helmets and the ones who did not during bicycle and e-bicycle accidents were analyzed and the mortality rate in a bicycle accident was I. $2 \%(n=6 / 484)$ and the cause of mortality was intracranial hemorrhage. Baschera et al. determined the average age of the bicycle accident group to be 41 . In this study, the average age was $24.14 \pm 11.95$. The high mortality rate in the study of Baschera et al. can be linked to the higher average age comparing to our study. It is stated in the literature that mortality increases in head traumas in line with the increasing age. ${ }^{[26-29]}$ The reason for no relationship between mortality and age in this study would be the young age range of the sample group.

Baschera et al. ${ }^{[18]}$ determined that $22 \%(n=4 I)$ of the patients with subdural bleeding consisted of bicycle users without helmets and examined the relationship between those who use helmets and those who do not use them in bicycle and e-bicycle accidents. In the same study, 9.1\% $(n=17)$ of patients with epidural bleeding consisted of bicycle users without helmets. In this study, the rate of subdural bleeding was $0.4 \%(n=6)$ and the epidural bleeding rate was $0.1 \%(n=2)$ in the accident of all users without a helmet, and only $25 \%$ of the mortal $(n=3)$ had subdural bleeding, $16.7 \%(n=2)$ had epidural bleeding $(p=0.000)$. As a result, it can be pointed out that subdural and epidural bleeding is not a significant and sole cause of mortality.

The ISS scores of the mortal group ranged between 25-75 and had an average value of $29.25 \pm 14.410$, all of the mortal ones had a major ISS score (ISS score >16), and as a result, there was a highly significant relationship between high ISS score and mortality $(p=0000)$. Heng et al. ${ }^{[2]}$ indicated the average rate of ISS score as 8.9. In the same study, the mortality rate in those who did not use helmets was found to be $2.1 \%$, and it was stated that there was a statistically significant relationship between mortality and high ISS score $(p<0.05)$. 
In conclusion, while bicycle accidents may occur in all age groups, they are more common among the young age groups. Head/neck trauma and intraparenchymal bleeding is an important cause of mortality in this type of injury. It was observed that the victims were not taking security measures, such as helmets. The patients to be discharged should be aware of the use of protective equipment, such as helmets, gloves and glasses.

Ethics Committee Approval

The study was approved by the Kartal Dr. Lütfi Kırdar City Hospital Ethics Committee (date: 28.01.2019, no: 2019/5 I4//46/I2).

Peer-review

Internally peer-reviewed.

Authorship Contributions

Concept: A.U.S., N.H.M.; Design: A.U.S., N.M.H., S.Ş.; Supervision: E.Y., R.A.; Fundings: A.U.S.; Materials: N.M.H., S.Ş.; Data: N.M.H., S.Ş., R.A.; Analysis: A.U.S., S.Ş., E.Y.; Literature search: E.Y., R.A., A.U.S.; Writing: A.U.S., N.M.H., S.Ş.; Critical revision: A.U.S., N.M.H., R.A., E.Y.

\section{Conflict of Interest}

None declared.

\section{REFERENCES}

1. Koçak S, Uçar K, Bayır A, Ertekin B. Acil servise başvuran motorsiklet ve bisiklet kazası olgularının karakteristikleri. Turk J Emerg Med 2010;10:112-8.

2. Heng KWJ, Lee AHP, Zhu S, Tham KY, Seow E. Helmet use and bicycle-related trauma in patients presenting to an acute hospital in Singapore. Singapore Med J 2006;47:367-72.

3. Ji M, Gilchick RA, Bender SJ. Trends in helmet use and head injuries in San Diego County: the effect of bicycle helmet legislation. Accid Analysis Prev 2006;38:128-34. [CrossRef]

4. Brown RL, Koepplinger ME, Mehlman CT, Gittelman M, Garcia VF. All-terrain vehicle and bicycle crashes in children: epidemiology and comparison of injury severity. J Pediatr Surg 2002;37:375-80.

5. Güzel A, Ersoy B, Doğrusoy Y, Küçükuğurluoğlu Y, Altinel T, Karasalihoğlu $\mathrm{S}$. The evaluation of bicycle accidents that were admitted to a pediatric emergency department. Ulus Travma Acil Cerrahi Derg 2006;12:299-304.

6. Emniyet Genel Müdürlüğü Trafik Hizmetleri Başkanlığı. Trafik istatistik bülteni. Available at: http://www.trafik.gov.tr/kurumlar/ trafik.gov.tr/04-Istatistik/Aylik/2018.pdf. Accessed Jun 16, 2019.

7. Simmons E, Kay M, Ingles A, Khurana M, Sulmont M, Lyons W. Evaluating the economic benefits of nonmotorized transportation: case studies and methods for the nonmotorized transportation pilot program communities. Paper No: DOT-VNTSC-FHWA-14-03; FHWA-HEP-15-027). Available at: https://rosap.ntl.bts.gov/view/ dot/12173. Accessed Feb 17, 2021.

8. National Highway Traffic Safety Administration. Traffic safety facts 2010 data: bicyclists and other cyclists. DOT HS, 810, 986. Available at: https://crashstats.nhtsa.dot.gov/Api/Public/ViewPublication/811624. Accessed Feb 17, 2021.

9. Wang H, Palm M, Chen C, Vogt R, Wang Y. Does bicycle network level of traffic stress (LTS) explain bicycle travel behavior? Mixed results from an Oregon case study. J Transp Geogr 2016;57:8-18.

10. Juhra C, Wieskoetter B, Chu K, Trost L, Weiss U, Messerschmidt M. Bicycle accidents-Do we only see the tip of the iceberg?: a prospective multi-centre study in a large German city combining medical and police data. Injury 2012;43:2026-34. [CrossRef]

11. van Baar GJ, Ruslin M, van Eijnatten M, Sándor GK, Forouzanfar T, Wolff, J. 3D assessment of damaged bicycle helmets and corresponding craniomaxillo-mandibular skull injuries: a feasibility study. Injury 2017;48:2872-8. [CrossRef]

12. Resmi Gazete. Karayolları trafik yönetmeliğinde değişiklik yapılmasına dair yönetmelik. Available at: https://www.resmigazete.gov.tr/ eskiler/2007/05/20070518-8.htm. Accessed Feb 17, 2021.

13. Güngör F, Oktay C, Topaktaş Z, Akçimen M. Analysis of motorcycle accident victims presenting to the emergency department. Ulus Travma Acil Cerrahi Derg 2009;15:390-5.

14. Thompson DC, Rivara FP, Thompson R. Helmets for preventing head and facial injuries in bicyclists. Cochrane Database Syst Rev 2000;1999:CD001855. [CrossRef]

15. Attwell RG, Glase K, McFadden M. Bicycle helmet efficacy: a metaanalysis. Accid Anal Prev 2001;33:345-52. [CrossRef]

16. Zibung E, Riddez L, Nordenvall C. Helmet use in bicycle trauma patients: a population-based study. Eur J Trauma Emerg Surg 2015;41:517-21. [CrossRef]

17. Cripton PA, Dressler DM, Stuart CA, Dennison CR, Richards D. Bicycle helmets are highly effective at preventing head injury during head impact: head-form accelerations and injury criteria for helmeted and unhelmeted impacts. Accid Analysis Prev 2014;70:1-7. [CrossRef]

18. Baschera D, Jäger D, Preda R, Z'Graggen WJ, Raabe A, Exadaktylos $\mathrm{AK}$, et al. Comparison of the incidence and severity of traumatic brain injury caused by electrical bicycle and bicycle accidents-a retrospective cohort study from a Swiss level i trauma center. World Neurosurg 2019;126:1023-34. [CrossRef]

19. Hu F, Lv D, Zhu J, Fang J. Related risk factors for injury severity of e-bike and bicycle crashes in Hefei. Traffic Inj Prev 2014;15:319-23.

20. Scholten AC, Polinder S, Panneman MJ, Van Beeck EF, Haagsma JA. Incidence and costs of bicycle-related traumatic brain injuries in the Netherlands. Accid Analysis Prev 2015;81:51-60. [CrossRef]

21. Du W, Yang J, Powis B, Zheng X, Ozanne-Smith J, Bilston L, et al. Epidemiological profile of hospitalised injuries among electric bicycle riders admitted to a rural hospital in Suzhou: a cross-sectional study. Inj Prev 2014;20:128-33. [CrossRef]

22. Dagher JH, Costa C, Lamoureux J, De Guise E, Feyz M. Comparative outcomes of traumatic brain injury from biking accidents with or without helmet use. Can J Neurol Sci 2016;43:56-64. [CrossRef]

23. Dinh MM, Kastelein C, Hopkins R, Royle TJ, Bein KJ, Chalkley DR, et al. Mechanisms, injuries and helmet use in cyclists presenting to an inner city emergency department. Emerg Med Australas 2015;27:323-7. [CrossRef]

24. Neumann MV, Eley R, Vallmuur K, Schuetz M. Current profile of cycling injuries: a retrospective analysis of a trauma centre level 1 in Queensland. Emerg Med Australas 2016;28:90-5. [CrossRef]

25. Özkan S, Akdur O, İkizceli İ, Durukan P, İpekci A, Mütevelli Sözüer E. Bicycle related injuries in adults and children in the central anatolian region: analysis of 4 years. JAEM 2012;11:35-40. [CrossRef]

26. Otte D, Facius T, Mueller C. Pedelecs in road traffic accidents and comparison to conventional non-motorized bicycles. VKU Verkehrsunfall und Fahrzeugtechnik 2014;52:48-60.

27. Ekman R, Welander G, Svanström L, Schelp L, Santesson P. Bicycle-related injuries among the elderly-a new epidemic? Public Health 2001;115:38-43. [CrossRef]

28. Susman M, DiRusso SM, Sullivan T, Risucci D, Nealon P, Cuff S, et al. Traumatic brain injury in the elderly: increased mortality and worse functional outcome at discharge despite lower injury severity. J Trauma 2002;53:219-24. [CrossRef]

29. Eilert-Petersson E, Schelp L. An epidemiological study of bicycle-related injuries. Accid Anal Prev 1997;29:363-72. [CrossRef] 


\section{Adalardaki Turist Bisiklet Kazaları: Bir Geriye Dönük Kohort Çalışma}

Amaç: Bisiklete bağlı yaralanmalar nedeniyle acil servise başvuran olguların karakteristik özelliklerini belirlemek amaçlanmıştır.

Gereç ve Yöntem: Epidemiyolojik, geriye dönük ve tanımlayıcı bir çalışma olarak planlandı. Çalışmada 20।4-20।9 yıllarında S.B.Ü. İstanbul Kartal Dr. Lütfi Kırdar Eğitim ve Araştırma Hastanesinin Acil Servis'ine bisiklete bağlı yaralanmalar nedeniyle Adalar bölgesinden başvuran olgular geriye dönük olarak incelendi. Veriler hastanenin bilgisayar ortamında kayıtlı olan hasta dosyası kayıtları incelenerek kaydedildi. Son beş yıla ait hasta kayıtları incelenerek bisiklet kazası olgularına ait veriler; sosyodemografik özellikler, kaza ile ilgili özellikler, travma özellikleri ve mortalite özellikleri açısından değerlendirildi.

Bulgular: Çalışmaya 1582 hasta dahil edildi. Hastaların \%58.I'i $(n=919)$ erkek, yaş ortalaması 24.14 I I.95'dir. Hastaların hiçbirinde kişisel korucu önlem (kask, dizlik vb) yoktu. En çok travmaya maruz kalan bölgeler, alt/üst ekstremite \%63.2 ( $\mathrm{n}=993)$, baş/boyun \%2l ( $\mathrm{n}=333$ ) bölgeleriydi. Mortalite oranı ise \%0.8 $(n=12)$ olarak bulundu.

Sonuç: Bisiklet kazalarında genç yaş grubundakiler etkilenmiştir. Baş/boyun travması ve intraparankimal kanamanın mortalite nedeni olduğu görülmüştür. Kazazedelerin kask gibi güvenlik önlemlerini kullanmadığı saptanmıştır.

Anahtar Sözcükler: Acil servis; baş/boyun travması; bisiklet; travma. 